\title{
A Study on the Diversity and Distribution of Sphecoid fauna in Thrissur District, Kerala, INDIA.
}

\author{
Baaby Job $^{1}$, Joseph Louis Olakkengil ${ }^{2}$ \\ (Department of Zoology, St.Thomas College, Thrissur).
}

\begin{abstract}
Sphecoid wasps comes under the Superfamily Apoidea, with species distributed throughout the world. They are mainly beneficial and relatively harmless to man. This paper provides a report on Sphecid wasps collected from six localities in and around Thrissur district, Kerala. The wasps were collected using hand nets. Ten species belonging to two subfamilies-Ampulicinae and Sphecinae were identified. Of the ten species, Chalybion bengalense Dahlbom showed highest distribution. The dominant genus was Sceliphron Klug (3species), while Ampulex Jurine and Trirogma Westwood were represented by one species each.A short note on biology is provided. A comparative analysis of species reported from Kerala and India is also provided.
\end{abstract}

Keywords: Ampulicinae, Distribution, Sphecidae, Sphecinae, Thrissur.

\section{Introduction}

Sphecidae (Latreille, 1802) is a cosmopolitan family of wasps with 9716 described species coming under 318 genera [1]. They are represented in all bio geographical regions and show great diversity in morphological and biological characters. Adult sphecids feed on a variety of food from nectar and honeydew to spiders and insects belonging to several orders. Prey paralysis and provisioning of nest is a common feature. Nests are constructed in soil, wood, plant stems, twigs and crevices or holes in rocks, stones, walls etc. Mating strategies include prenuptial flights, territorial defenses and courtship activities [2,3].

The sphecid wasps can be readily distinguished from their closest relatives, bees by the presence of simple unbranched hairs, pronotal lobe not touching tegulae and presence of cleaning pectan on inner side of hind basitarsus opposed to inner tibial spur. These wasps are associated with mankind in the field of agriculture and general ecology, acting as predators, pollinators, parasites and parasitoids. They are valuable bio indicators and biocontrol agents $[4,5]$.The relationship of these insects with man has been unfriendly due to fear from their over rated stinging powers.

Though most species of Spheciformes have been collected and described from Central and Northern parts of India, the sphecoid fauna of the country is still imperfectly known. The pioneer studies of Indian Spheciformes were done by Fabricius [6]. Bingham [7] has recorded as many as one sixty eight species of Sphecid wasps as occurring in the Indian Sub Continent. Later Cameron [8], Turner[9] has published on the Indian fauna. Bohart and Menke[3]published generic revision on the world fauna. The recent works on Indian sphecidae is by Gupta [10], Jonathan et.al [11,12] and Kundu et.al[13]. In Kerala 47 species of sphecid wasps has been listed $[14,15,16]$.The Sphecidae has been treated as a single family with 11 subfamilies [3] or as Superfamily with the subfamilies raised to family status[17].But later cladistic treatment has divided the sphecid wasps in four monophyletic families [18, 19].This paper follows the classification proposed by Bohart and Menke[3], as it is an authenticated revision on world Sphecidae, even till date.

The present papers aim to generate valuable information about the diversity and distribution of Sphecid wasps belonging to Subfamilies Ampulicinae and Sphecinae in Thrissur District of Kerala, as of now research on the sphecid wasp diversity has not been available for this area.

\section{Materials And Methods}

2.1. STUDY AREA: The study area includes six locations around Thrissur district-Ayyanthole, Chelakkottukara, Eravu, Peechi, Thumburmuzhi and Vazhani (Fig:1). Thrissur district lies at central part of kerala at sea level $\left(10.52^{\circ} \mathrm{N}\right.$ and $\left.76.21^{\circ} \mathrm{E}\right)$. The district is bounded on east by Western Ghats and consists of three natural divisionshighlands, plains and sea shore. The district has tropical humid climate with average temperature of $31^{\circ} \mathrm{C}$ and annual rain fall $3000 \mathrm{~mm}$. 
Figure1: Collection areas in Thrissur District

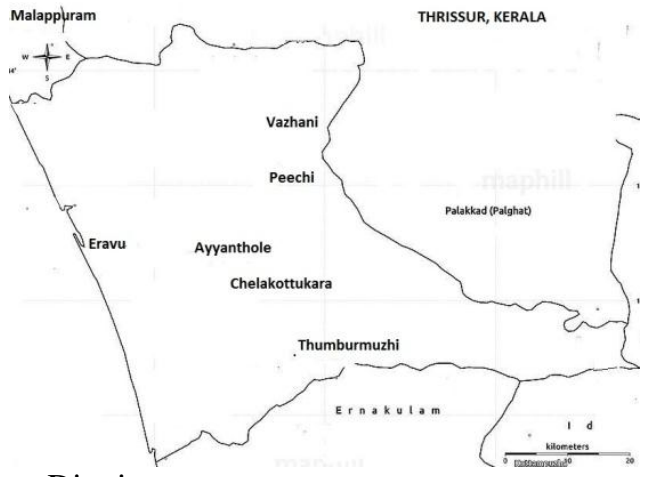

2.2. COLLECTION AND PRESERVATION: The insects were collected using hand nets, killed with Acetone, pinned with No. 3 Entomological pins and preserved in insect boxes for identification studies. The insects were collected random between 9 AM and 5 PM from August 2009 to February 2012.

2.3. IDENTIFICATION: The collected specimens were identified using Leica MZ6 Stereozoom microscope with camera lucida with the help of literature $[3,7,11,12,14]$

\section{Results}

A total of ten species belonging to six genera under two subfamilies- Ampulicinae and Sphecini, were collected from Thrissur district (TABLE 1).

Subfamily Ampulicinae

Tribe Ampulicini

Genus Ampulex Jurine, 1807

1. Ampulex compressa (Fabricius, 1781)

Sphex compressusFabricius, 1781

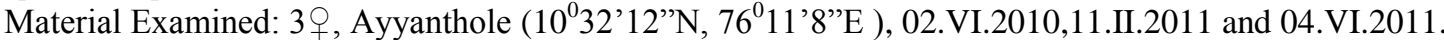

Kerala records: Fabricius, 1781 (Malabar)[20]; Sudheendrakumar and Narendran, 1989(Malabar).

Tribe Dolichurini

Genus TrirogmaWestwood, 1841

2. Trirorma caerulea (Westwood, 1841)

Trirogma caeruleaWestwood, 1841

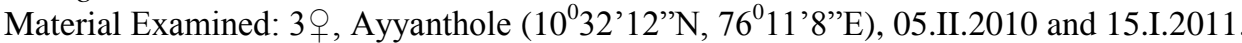

Kerala records:Sudheendrakumar and Narendran, 1989(Malabar); Sudheendrakumar and Mathew, 1999 (Parambikulam Wildlife Sanctuary).

Subfamily Sphecinae

Tribe Ammophilini

Genus AmmopilaW.Kirby, 1798.

3. Ammophila clavus (Fabricius, 1775)

Sphex clavusFabricius, 1775

Material Examined: 1q, Ayyanthole, 03.III.2009; 1 , Vazhani, 03.01.2010.

Kerala Records: Sudheendrakumar and Narendran, 1989(Malabar); Sudheendrakumar and Mathew, 1999 (Parambikulam Wildlife Sanctuary).

4. Ammophila laevigata (F.Smith, 1856).

Ammophila laevigata (F.Smith,1856).

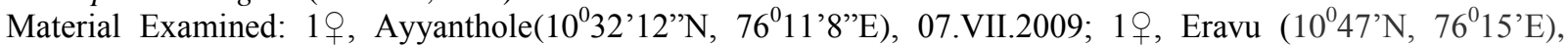
11.III.2011.

Kerala Records: Sudheendrakumar and Narendran, 1989(Malabar); Sudheendrakumar and Mathew, 1999 (Parambikulam Wildlife Sanctuary).

Tribe Sceliphrini

Genus Sceliphron Klug, 1801

5. Sceliphron coromandelicum (Lepletier, 1845)

Pelopaeus coromandelicus Lepeletier de Saint Fargeau, 1845.

Material Examined: 1ㅇ, Peechi(10³1'47"N 76²2'13"E), 12.II.2012.

Kerala Records: Sudheendrakumar and Narendran, 1989(Malabar); Sudheendrakumar and Mathew, 1999 (Parambikulam Wildlife Sanctuary). 
6. Sceliphron javanum nalandicum (Strand, 1915)

Pelopoeus spinolae: F. Smith, 1856.

Material Examined: 1 , , Thumburmuzhi $\left(10^{0} 29\right.$ N, $76^{0} 46^{\prime}$ E), 05.V.2012.

Kerala Records: Sudheendrakumar and Narendran, 1989(Malabar); Sudheendrakumar and Mathew, 1999 (Parambikulam Wildlife Sanctuary).

7. Sceliphron madraspatanum (Fabricius, 1781)

Sphex madraspatanusFabricius, 1781

Materials examined: 3 ㅇ, Ayyanthole $\left(10^{0} 32^{\prime} 12^{\prime \prime} \mathrm{N}, 76^{0} 11^{\prime} 8^{\prime \prime} \mathrm{E}\right), 02.1 .2010$ and 13.IV.2010.

Kerala Records:Fabricius, 1781(Malabar); Sudheendrakumar and Narendran, 1989(Malabar); Sudheendrakumar and Mathew, 1999 (Parambikulam Wildlife Sanctuary).

8. Chalybion bengalense (Dahlbom, 1845)

Genus ChalybionDahlbom, 1843.

Sphex violaceus Fabricius, 1775 .

Materials examined: 2 , Ayyanthole $\left(10^{0} 32^{\prime} 12^{\prime \prime} \mathrm{N}, 76^{0} 11^{\prime} 8^{\prime \prime} \mathrm{E}\right), 02.1 .2010 ; 1$, Eravu $\left(10^{0} 47^{\prime} \mathrm{N}, 7^{0} 15^{\prime} \mathrm{E}\right)$,

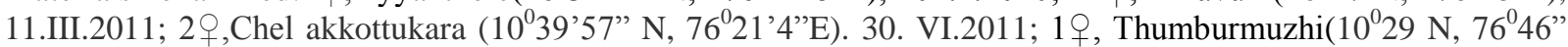
E), 05.II.2012.

Kerala Records: Sudheendrakumar and Narendran, 1989(Malabar); Sudheendrakumar and Mathew, 1999 (Parambikulam Wildlife Sanctuary).

Tribe Sphecini

Genus Sphex Linnaeus, 1758.

9. Sphex argentatus (Fabricius, 1787)

Sphex argentatusFabricius, 1787

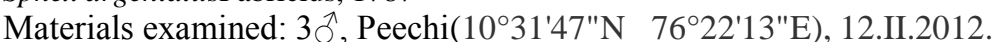

Kerala Records: Sudheendrakumar and Narendran, 1989(Malabar); Sudheendrakumar and Mathew, 1999 (Parambikulam Wildlife Sanctuary).

10. Sphex sericeus (Fabricius, 1793)

Sphex aurulentusFabricius, 1793

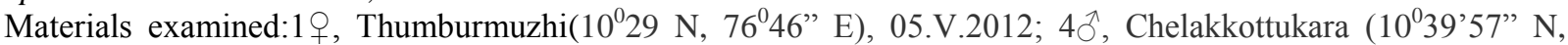
76 21'4'E). 30. VI.2011 and 18.VII.2011.

Kerala Records: Sudheendrakumar and Narendran, 1989(Malabar); Sudheendrakumar and Mathew, 1999 (Parambikulam Wildlife Sanctuary).

Table: 1Systematic position of Sphecid wasps in Thrissur District, Kerala.

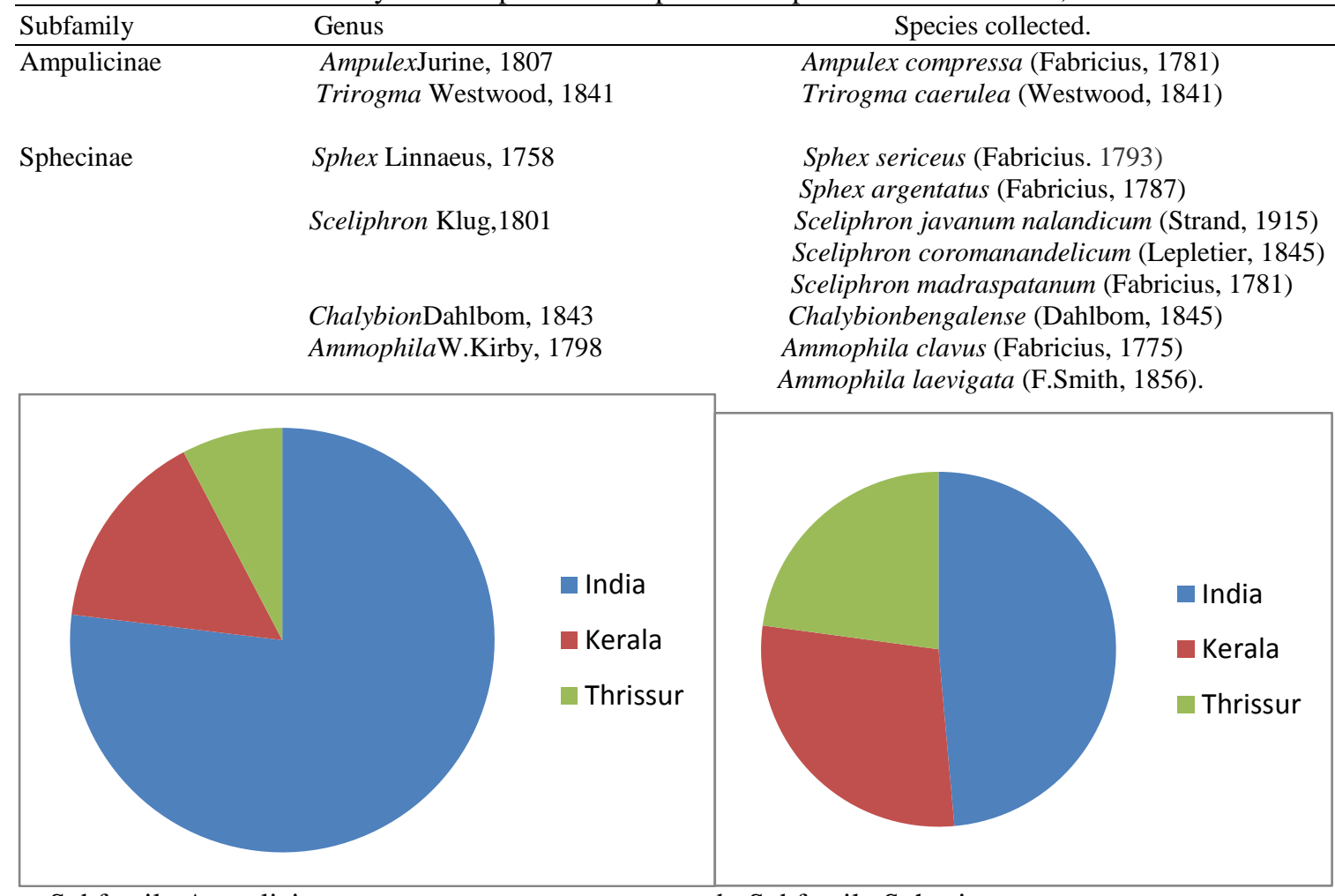

a: Subfamily Ampulicinae

b: Subfamily Sphecinae

Figure 2: Pie diagram comparing number of Species reported from Thrissur to Kerala and India. 


\section{Discussions}

In the present study ten species of sphecid wasps in six genera representing two subfamilies were recorded. The subfamily Sphecinae recorded eight species under four genera, while subfamily Ampulicinae represented two species under two genera.

Among the genus Sceliphron Klug recorded the most number of species. These together with Chalybion bengalense Dahlbom are called mud-dauber wasps, on account of their habit of building multicellular mud nests. These can be readily recognized in the fields by their black and yellow body, while C.bengalense has metallic blue body.They mass provision their nests with spiders. Among the species C.bengalense was the most represented with collections recorded from four of the six localities, a possible outcome of prey abundance.Sceliphron javanum nalandicum Strand was recorded only from Thumburmuzhy area.

Sphex Linnaeus are fossorial wasps, their nests are holes dug in soil and provisioned with Acrididae. Sphex sericeus Fabricius females are readily recognized by their golden yellow body, while males have black and red body with white hairs. The males were collected feeding from flowers of Murraya koenigii (L) Spreng. Sphex argentatus Fabricius are robust black species. Ammophilini are called thread waisted wasps, with slender, black and red body. Their petiole is two segmented. These are solitary nesters feeding on lepidopteran larva. They were the most difficult to catch usually escaping from the nests while sweeping.

Ampulex compressa Fabricius and Trirogma caerulea Westwood were collected from Ayyanthole locality only.A.compressa are metallic green blue body and were collected from trunks of Coccus nucifera Linnaeus, possibly in search of their prey, Periplaneta americana Linnaeus.

A pie diagram showing the comparison between the number of species reported from Thrissur to species recorded from the above genus' in Kerala and India is given for both subfamilies. In India, the number of species reported from the four genus of Subfamily Sphecinae is 17 and from Kerala is 10 (Fig.2a), while the number of species reportedfrom Subfamily Ampulicinae in India is 20 and in Kerala is 4 (Fig 2b).

\section{Conclusions}

The occurrence of Spheciformes in a habitat is conditioned by moisture, the soil exposure, soil type and prey abundance [21].The collection of these wasps are a tedious process, yet they have to be catalogued because of their economic importance.In determining the fauna of a country, faunistical studies on small regions is very important because individual habitats and the micro climate in a small region plays an important role on the distribution of insects [21].These wasps are mainly feared by humans due to their overrated stinging powers and their close association with human habitats results in the destructions of nests by humans. These wasps perform many ecological roles as predators, pollinators, bio control agents and biodiversity indicators [22]. Present study has revealed valuable information on the wasps of Thrissur region and future studies may result in further elaboration of these wasp species. Also studies on the ecology of these diverse wasps need to be carried out.

\section{Acknowledgements}

We wish to extend our gratitude to Dr.T.C. Narendran, ZSI, Kozhikode for his guidance, support and encouragement. We wish to acknowledge Dr.Sr. Karmaly K.A., Dept. of Zoology, St.Xaviers College, Aluva for the lab facilities and support. The first author wishes to acknowledge UGC for the MANF Scholarship-09. The first author also acknowledges Presty John, Sacred Heart College, Thevara and Dr.P.Lakshmi Devi Menon for their encouragement and support.

\section{References}

[1] Pulawski. W. J, Catalogue of Sphecidae at California Academy, www.research.catacademy.org.

[2] Ashmead W.H. The habits of Aculeate Hymenpotera-III, Psyche. 7, 1894, 59-66.

[3] R.M. Bohart and A.S.Menke, Sphecid wasps of the world a Generic Revision(University of California Press, California.1976).

[4] Gayubo, S. F., González, J. A., Asís, J. D. and Tormos, J. Conservation of European Environments: The Spheciformes Wasps as biodiversity indicators ( Hymenoptera: Apoidea: Ampulicidae, Sphecidae and Crabronidae). Journal of Natural History.39 (29), 2005, $2705-2714$.

[5] Borror D.J. and DeLong D.M Introduçãoaoestudo dos insectos.Brasil,EditoraEdgardBlücher Ltd, 1988 , pp. 417 - 486.

[6] J.C.Fabricius, .Systemaentomolgiae, etc. (Kortii, FlensburgietLipsiae 1775) xxviii+832 pp.

[7] C.T Bingham, The Fauna of British India Hymenoptera- Volume I, (London:Taylor and Francis, 1897) xiii and 579pp.

[8] P.Cameron, Insecta, Hymenoptera, in F.D. Godman and D.Salvin (Ed), Volume 2,Fossores(London: Taylor and Francis, 18881890) pp 1-32=1888, 33-64=1889, 65-128=1890, 129-176=1891, Sphecidae=pp 1-158.

[9] R.E. Turner. Notes on fossorial Hymenoptera.Annals and Magazines of Natural History.8(10).1912. 48-63.

[10] S.K.Gupta, Hymenoptera, Zoological Survey of India. Himalaya Ecosystem Series, Uttar Pradesh. Part 1, 1995, 81-89

[11] J.K.Jonathan, K.K.Ray and B.G.Kundu.Insecta: Hymenoptera:Sphecidae, Zoological Survey India, Fauna of Meghalaya, State Fauna Series, 4(7), 2000, 161-222.

[12] J.K.Jonathan and B.G.Kundu.Insecta: Hymenoptera:Sphecidae, Zoological Survey India, Fauna of Sikkim, State Fauna Series, 9(4), 2003, 417-446.

[13] B.G.Kundu,S.N.Ghosh and R.N.Tiwari, Insecta: Hymenoptera:Aculeata: Sphecidae, Zoological Survey India, Fauna of Arunachal Pradesh, State Fauna Series, 13 (2),2006, 399-426.

[14] V.V. Sudheendrakumar and T.C.NArendran, Sphecoid wasps of Kerala, India, Sphecos, 18, 1989, 11-12. 
[15] Madhavikutty M, Description of a new species of genus Trirogma Westwood (Hymenoptera: Spheciformes) from India, Perspectives on Biosystematics and Biodiversity, T.C.N.Com. Volume, 2004, 593-596.

[16] V.V. Sudheendrakumar and George Mathew, Sudies on the diversity of selected group of insects in the Parambikulam wildlife sanctuary, kerala Forest Research Institute 165, 1999, pp77.

[17] A.T Finnamore.and Charles D. Michener.Super Family Apoidea. In Henri Goulet and John T. Huber(Ed. ), Hymenoptera of the world - an identification guide to families (Canada: Research Branch, Agriculture, 1993). p. 279 - 346.

[18] G.A.R. De Melo, Phylogenetic relationships and classification of the major lineages of Apoidea (Hymenoptera), with emphasis on crabronid wasps.Scientific Papers. Natural History Museum. The University of Kansas 14, 1999, 1-55.

[19] D.J. Brothers, Phylogeny and evolution of wasps, ants and bees (Hymenoptera, Chrysidoidea, Vespoidea and Apoidea), ZoologicaScripta28, 1999, 233-249.

[20] J.C Fabricius. Mantissa insectorum I, Hamb.et kilonii, 1781, pp 552.

[21] YasarGulmez and AylaTuzun, Spheciformes (Hymenoptera: Apoidea) from Ankara province, Subfamilies Sphecinae, Pemphredoninae and Astatinae. J.Ent. Res. Soc, 7 (1), 2005, 41-57.

[22] S. F.Gayubo, J. A.González and F. Torres, Estudio de unacomunidad de esfécidosen la zona natural de "Las Arribes del Duero" ( Salamanca, Oesteespañol ) ( Hymenoptera, Sphecidae ). FragmentaEntomologica, 32, 2000, 181-209. 